\title{
SECRETAGOGUE INDUCED CALCIUM MOBILIZATION IN SINGLE PANCREATIC ACINAR CELLS
}

\author{
Edward L. Stuenkel, Yasuhiro Tsunoda, and John A. Williams \\ Department of Physiology, University of Michigan, Ann Arbor, MI 48109
}

Received October 12,1988

Summary: Microspectrofluorometry of fura-2 was utilized to monitor $\left[\mathrm{Ca}^{2+}\right]_{i}$ in single acinar cells stimulated with a cholinergic agonist and cholecystokinin. A similar amplitude of agonist induced $\mathrm{Ca}$ mobilization between single cell and populational approaches was observed. New findings in single cells not observable in populations of cells include: 1) the maintenance of a sustained elevation in $\left[\mathrm{Ca}^{2+}\right]_{\mathrm{i}}$ above basal levels throughout agonist application, 2) the reloading of the agonist-sensitive Ca pool only following removal of the agonist and 3) the presence of oscillations of $\left[\mathrm{Ca}^{2+}\right]_{i}$ in response to agonist application which is enhanced at lower agonist concentrations.

- 1989 Acadenic Press, Inc.

Acetylcholine and cholecystokinin stimulate pancreatic acinar cell enzyme secretion through generation of inositol 1,4,5-trisphosphate and 1,2-diacylglycerol which induce mobilization of calcium from intracellular stores and activation of protein kinase $\mathrm{C}$ respectively (1). In addition, sustained secretagogue stimulation apparently causes an activation of $\mathrm{Ca}$ influx across the plasma membrane. This latter mechanism is believed to remain activated following secretagogue removal thereby allowing entry of extracellular $\mathrm{Ca}$ and refilling of the intracellular agonist-sensitive Ca pool (2). Characterization of these changes in $\left[\mathrm{Ca}^{2+}\right]_{\mathrm{i}}$ have recently been studied using $\mathrm{Ca}$-sensitive fluorescent indicators such as quin2 and fura-2 (3-8). To date, however, the use of fluorescent probes has been performed on populations of isolated acini under static conditions. This arrangement results in a number of experimental shortcomings. These include: 1) changes in $\left[\mathrm{Ca}^{2+}\right]_{i}$ reflect an integrated response over a large number of cells which may not be representative of temporal changes in $\left[\mathrm{Ca}^{2+}\right]_{i}$ in single acinar cells. 2) removal of agonist activation relies on application of an antagonist and 3 ) an increasing background dye signal may result from dye leakage and mechanical damage of a percentage of the stirred acini.

The purpose of the present study was to utilize dual wavelength microspectrofluorometry of fura- 2 to examine the secretogogue induced changes in $\left[\mathrm{Ca}^{2+}\right]_{i}$ in superfused single acinar cells. The results indicate that individual acinar cells posses a releasable $\mathrm{Ca}^{2+}$ pool responsive to multiple agonists. Heretofore unreported oscillations of intracellular $\mathrm{Ca}^{2+}$ were also observed. 


\section{MATERIALS AND METHODS}

Acini were prepared from pancreas of male Sprague-Dawley rats (200-250g) according to the collagenase digestion procedure detailed by Williams et al. (9). Isolated acini were incubated with $2 \mu \mathrm{M}$ fura-2AM at $37^{\circ} \mathrm{C}$ in a physiological salt solution (PSS) containing (in $\mathrm{mM}$ ): $\mathrm{NaCl}, 145 ; \mathrm{K}_{2} \mathrm{HPO}_{4}, 2.5 ; \mathrm{CaSO}_{4}, 1.0 ; \mathrm{MgSO}_{4}, 1.0 ;$ glucose, 10 ; HEPES, 10; bovine serum albumin, $0.5 \mathrm{mg} / \mathrm{ml}$; soybean trypsin inhibitor, $0.1 \mathrm{mg} / \mathrm{ml}$; which was adjusted to $\mathrm{pH} 7.4$ with $\mathrm{NaOH}$. During the $15 \mathrm{~min}$ incubation period the acini received continuous oxygenation and shaking ( $30 \mathrm{cycles} / \mathrm{min}$ ). Acini loaded with fura-2 were collected by centrifugation at $50 \times \mathrm{g}$ and resuspended in saline. PSS utilized during the fluorescence measurements was identical to that given above except that BSA and trypsin inhibitor were omitted. In addition nominally Ca-free PSS was prepared by omitting the $\mathrm{CaSO}_{4}$ and adding $1 \mathrm{mM}$ EGTA.

Measurement of $\left[\mathrm{Ca}^{2+}\right]_{\mathrm{i}}$. Fluorescence measurements of fura-2 loaded acini were performed on both populations of acinar cells as well as at the level of single acinar cells. Populational studies were performed by attaching acini to cover slips with Cell-Tak (Biopolymers; Farmington, CT) which were then inserted into a cuvette along the diagonal axis and placed into the spectrofluorometer chamber regulated to $37^{\circ} \mathrm{C}$. A superfusion system with a flow rate of $10 \mathrm{ml} / \mathrm{min}$ provided rapid exchange of the cuvette volume $(2 \mathrm{ml})$. To measure fluorescence of single acinar cells, acini were attached to glass cover slips mounted in a chamber $(0.1 \mathrm{ml}$ volume $)$ regulated at $37^{\circ} \mathrm{C}$ which allowed continuous superfusion at $1 \mathrm{ml} / \mathrm{min}$ with switching of solutions. The chamber was mounted on the stage of a Nikon Diaphot inverted microscope equipped with a $40 \mathrm{X}$ oil immersion epifluorescence lens $(\mathrm{NA}=1.3)$. Single acinar cells were optically masked using a pinhole diaphragm stopped down to an optical diameter of $10 \mu \mathrm{m}$.

All studies utilized a Spex fluorolog spectrofluorometer system to generate 340 and $380 \mathrm{~nm}$ excitation wavlengths and for collection and analysis of emitted photon counts. Emitted light was monitored at an emission wavlength of $505 \mathrm{~nm}$ for populational studies or following passage through a barrier filter $(480 \mathrm{~nm})$ for single cell experiments. In both cases photon counts were averaged over intervals of $0.5 \mathrm{sec}$ at each wavlength. For populational studies intensity ratios (340/380 excitation) were calculated after subtracting autofluorescence of acini without fura-2 at each wavelength. Autofluorescence at the level of single acinar cells was, however, found to constitute less than $6 \%$ of the emitted signal and was not subtracted. For all studies, the fluorescence ratio $(340 / 380)$ was converted to $\left[\mathrm{Ca}^{2+}\right]_{\mathrm{i}}$ using the equation of Grynkiewicz et al. (10). For single cell studies, Kd, Fmin, Fmax, and $\mathrm{Fo} / \mathrm{Fs}$ values of $224 \mathrm{nM}, 0.8,18.62$ and 4.61 respectively, were used, as determined using cytoplasmic resembling solutions at fixed $\left[\mathrm{Ca}^{2+}\right]$ containing $25 \mathrm{M}$ fura-2. For populational studies the formula $340 / 380=-3.72(\mathrm{pCa})+29.05$ was used to calculate $\left[\mathrm{Ca}^{2+}\right]$, as determined from the linear portion of the relationship, using solutions of fixed $\left[\mathrm{Ca}^{2+}\right]$ containing $1.2 \mu \mathrm{M}$ fura-2.

\section{RESULTS}

\section{Comparison of populational and single cell measurements.}

A comparison of fluorescent measurements from the cover slip/cuvette approach, which averages fluorescence over a large number of cells, with those obtained from single acinar cells and of their responsiveness to the cholinergic agonist carbachol $(\mathrm{CCh})$ is shown in Fig. 1. Mean basal and $\mathrm{CCh}$ stimulated $\left[\mathrm{Ca}^{2+}\right]_{i}$ values for the populational measurements were $114 \pm 12 \mathrm{nM}(\mathrm{n}=7$, $+\mathrm{SE}, 6$ preparations) and $420 \pm 78 \mathrm{nM}$ respectively. Basal and stimulated values determined in single cells were $136 \pm 15 \mathrm{nM}(\mathrm{n}=$ 28, 6 preparations) and $754 \pm 77$ respectively. CCh stimulated increases in $\left[\mathrm{Ca}^{2+}\right]_{i}$ were reproducibly higher using the single cell approach. In addition both noise and 

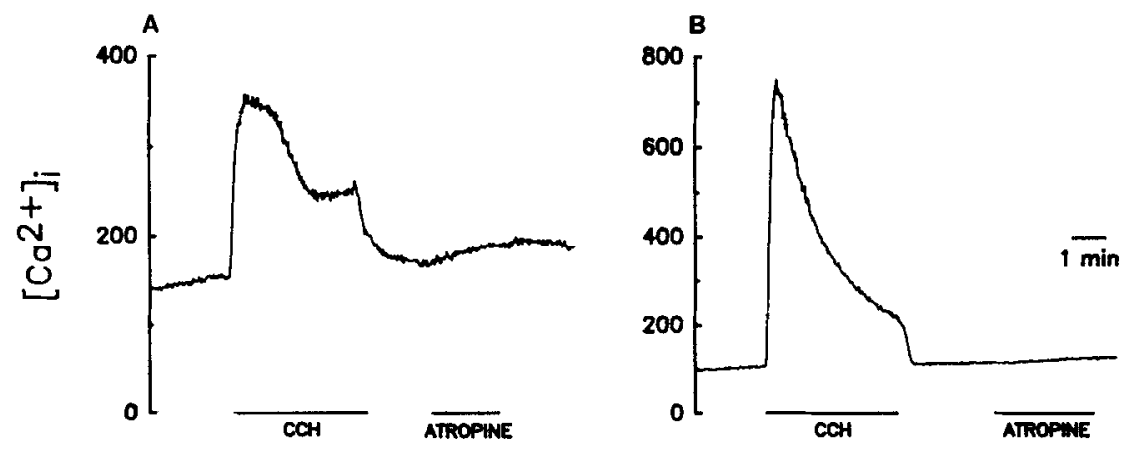

Figure 1. Comparison of $\mathrm{CCh}$ evoked changes in $\left[\mathrm{Ca}^{2+}\right]$, between populational and single cell approaches. A) $\mathrm{CCh}$ induced change in $\left[\mathrm{Ca}^{2+}\right]_{\text {; }}$ using a populational approach where the fluorescence signal is averaged from a large number of acini. B) Change in $\left[\mathrm{Ca}^{2+}\right]_{i}$ in a single acinar cell in response to a similar pulse of $\mathrm{CCh}$. In both instances $10 \mu \mathrm{M} \mathrm{CCh}$ was superfused over the cell preparation for a period of $4 \mathrm{~min}$ before return to PSS as indicated below the traces. Subsequent addition of $100 \mu \mathrm{M}$ atropine elicits no further decrease in $\left[\mathrm{Ca}^{2+}\right]_{i}$ substantiating complete washout of $\mathrm{CCh}$.

autofluorescence were significantly less. Application of $10 \mu \mathrm{M} \mathrm{CCh}$ for $4 \mathrm{~min}$ resulted in a transient rise in $\left[\mathrm{Ca}^{2+}\right]_{\mathrm{i}}$ which returned to near basal values within $2-3 \mathrm{~min}$ although remaining elevated at plateau values averaging $61 \pm 7 \mathrm{nM}(\mathrm{n}=28)$ above basal values for single cells. Removal of $\mathrm{CCh}$ rapidly returned $\left[\mathrm{Ca}^{2+}\right]_{i}$ to prestimulatory values.

Subsequent application of atropine after removal of the $\mathrm{CCh}$ showed no further change in $\left[\mathrm{Ca}^{2+}\right]_{\mathrm{i}}$ providing evidence for complete washout of the $\mathrm{CCh}$ stimulus.

\section{Recovery of agonist-sensitive Ca pool following CCh stimulation.}

The rapid reversibility of $\mathrm{CCh}$ application afforded by the superfusion system provides the opportunity to examine the responsiveness of single acinar cells to repetitive $\mathrm{CCh}$ stimuli following variable periods of recovery. Representative examples taken from single acinar cells receiving repetitive $\mathrm{CCh}$ pulses are shown in Fig. 2A-C. Recovery of the $\mathrm{Ca}$ response is clearly dependent on the length of the intervening interval between $\mathrm{CCh}$ tests with $65 \%$ recovery occurring after approximately $3 \mathrm{~min}$ (Fig. $2 \mathrm{~B}$ ) and greater than $90 \%$ recovery requiring 10 to $15 \mathrm{~min}$ (Fig. $2 \mathrm{C}$ and $2 \mathrm{D}$ ). Reloading of the agonist-sensitive Ca pool following agonist removal occurs without an elevation in the cytoplasmic $\left[\mathrm{Ca}^{2+}\right]_{\mathrm{i}}$ suggesting either highly synchronized extracellular $\mathrm{Ca}$ entry and sequestration or of direct reloading from extracellular $\mathrm{Ca}$ into the agonist-sensitive pool. Particularly interesting in Fig. 2B (see also Fig. 4D) is the presence of oscillations in $\left[\mathrm{Ca}^{2+}\right] \mathrm{i}$ during secretagogue application. Oscillations of this type at $10 \mu \mathrm{M}$ CCh were observed in approximately $40 \%$ (n $=34$ ) of cells examined at the level of the single cell but were never observed during secretagogue application in the populational studies.

\section{Effect of extracellular $\mathrm{Ca}$ on $\mathrm{CCh}$ responses.}

The effect of external $\mathrm{Ca}$ on the $\mathrm{CCh}$ induced increase in $\left[\mathrm{Ca}^{2+}\right]_{\mathrm{i}}$ and on responsiveness to a second $\mathrm{CCh}$ application is shown in Fig. 3. Application of $\mathrm{CCh}$ in $\mathrm{Ca}$ free medium resulted in an increase in $\left[\mathrm{Ca}^{2+}\right]_{i}$ whose amplitude showed close similarity to 

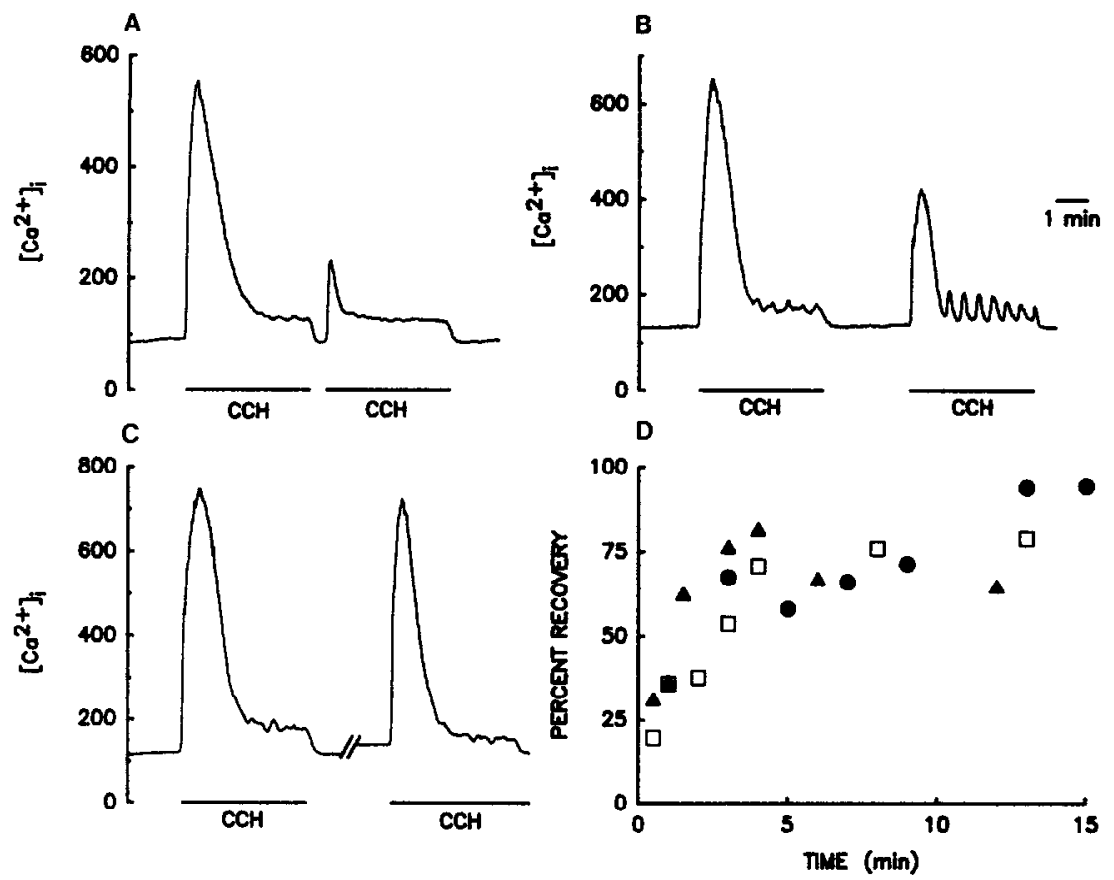

Figure 2. Time course of recovery of the agonist-sensitive Ca pool following $\mathrm{CCh}$ stimulation. Application of an initial CCh stimulation (4 min) is followed by a period in PSS of $0.5 \mathrm{~min}$ (A), $3 \mathrm{~min}(\mathrm{~B})$ or $10 \mathrm{~min}$ (C) before application of a second stimulation with CCh. D) Pooled results from 3 preparations (different symbols) showing the time course of recovery of the agonist sensitive Ca pool. Percent recovery is calculated from the $\mathrm{CCh}$ induced change from basal $\left[\mathrm{Ca}^{2+}\right]_{\mathrm{i}}$ of the second $\mathrm{CCh}$ pulse to that of the first. Note oscillations of $\left[\mathrm{Ca}^{2+}\right]_{i}$ in $\mathrm{B}$ which are augmented during the second $\mathrm{CCh}$ stimulus.

that of acini in Ca-containing medium. Mean basal and stimulated $\left[\mathrm{Ca}^{2+}\right]_{i}$ under these conditions were $129 \pm 10 \mathrm{nM}$ and $619 \pm 69 \mathrm{nM}$ ( $\mathrm{n}=5,3$ preparations) respectively. A second $\mathrm{CCh}$ challange $10 \mathrm{~min}$ later, under maintained $\mathrm{Ca}$-free conditions, resulted in a response on average only $12 \%(n=3)$ that of the initial response. Similar results were
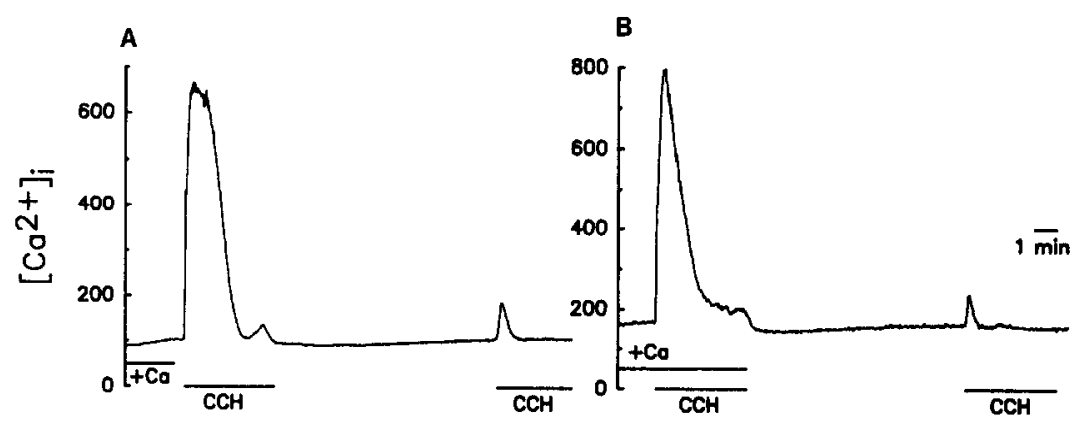

Figure 3. Effect of extracellular $\mathrm{Ca}$ on $\mathrm{CCh}$ evoked changes in $\left[\mathrm{Ca}^{2+}\right]_{\mathrm{f}}$ and recovery of the agonist sensitive Ca pool. A) Removal of extracellular Ca $0.5 \mathrm{~min}$ prior and during application of $10 \mu \mathrm{M}$ CCh is ineffective in altering the rise in $\left[\mathrm{Ca}^{2+}\right]_{\mathrm{i}}$. Sustaining Ca-free PSS for $10 \mathrm{~min}$ following removal of the initial CCh pulse reduces reloading of the agonistsensitive Ca pool as assesed by the amplitude of a second $\mathrm{CCh}$ pulse. B) Removal of extracellular $\mathrm{Ca}$ following an initial CCh pulse reduces reloading of the agonist-sensitive Ca pool to an extent similar to that shown in $\mathrm{A}$. 

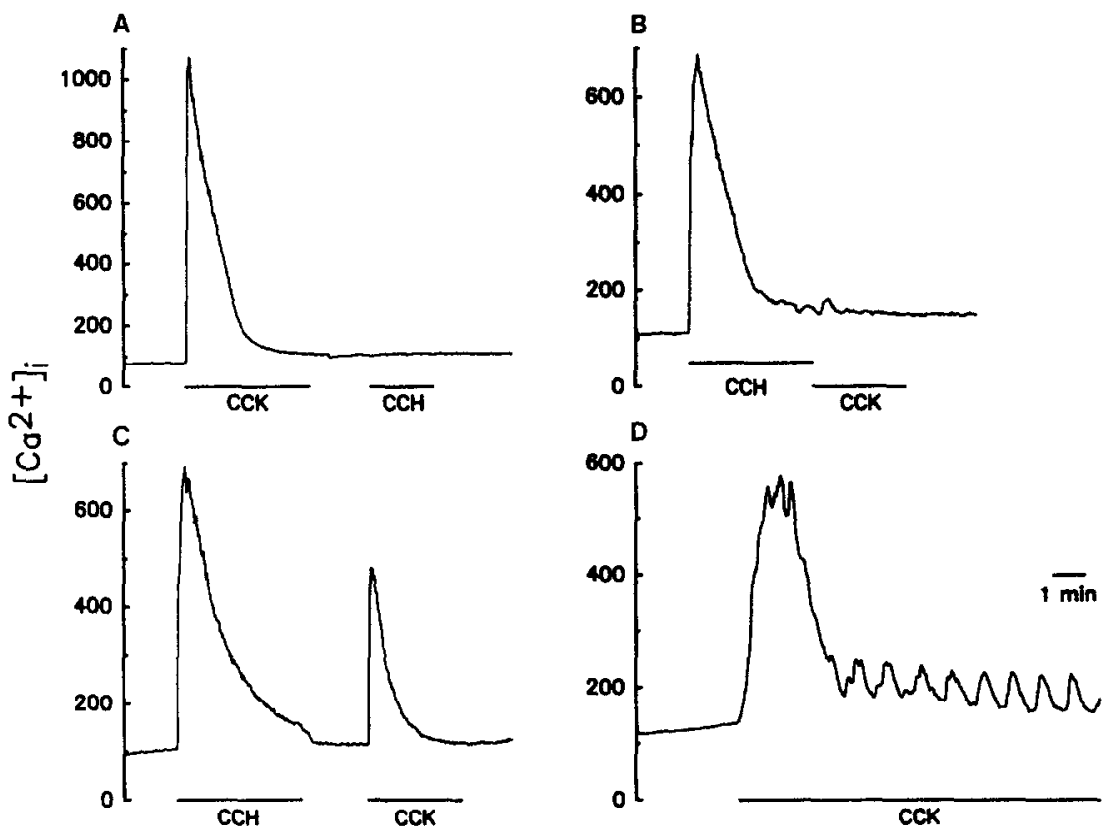

Figure 4. Comparison and interaction between $\mathrm{CCK}$ and $\mathrm{CCh}$ induced changes in $\left[\mathrm{Ca}^{2+}\right]_{\mathrm{i}}$ A) $\mathrm{CCK}(1 \mathrm{nM})$ evokes an increase in $\left[\mathrm{Ca}^{2+}\right]_{;}$similar in amplitude to that exhibited by $\mathrm{CCh}$. Note, however, that addition of $\mathrm{CCh}$ following $\mathrm{CCK}$ does not elicit a change in $\left[\mathrm{Ca}^{2+}\right]_{\mathrm{i}}$ B) Application of $\mathrm{CCK}$ subsequent but coincident with a $\mathrm{CCh}$ induced increase in $\left[\mathrm{Ca}^{2}\right]_{i}$ evokes no further change in $\left[\mathrm{Ca}^{2+}\right]_{i}$. C) Insertion of an interval in PSS following CCh stimulation allows partial recovery of the agonist sensitive Ca pool which responds to CCK stimulation. D) Application of CCK at a reduced concentration (0.1 $\mathrm{nM}$ ) results in enhancement of oscillations of $\left[\mathrm{Ca}^{2+}\right]_{i}$ which are sustained throughout agonist application.

obtained if $\mathrm{Ca}$ was present during the initial $\mathrm{CCh}$ stimulus but removed at the time of removal of $\mathrm{CCh}$ (Fig. 3B); the second response averaged $12 \%(\mathrm{n}=3)$ that of the initial response. This data indicates that reloading of the $\mathrm{CCh}$ sensitive intracellular $\mathrm{Ca}$ pool occurs primarily following removal of the CCh stimulus and is dependent on extracellular Ca.

\section{Interaction and comparison of $\mathrm{CCh}$ and $\mathrm{CCK}$ responses.}

Application of $1 \mathrm{nM} \mathrm{CCK}$ (Fig. 4A) resulted in an increase in $\left[\mathrm{Ca}^{2+}\right]_{\mathrm{i}}(683 \pm 150$ $\mathrm{nM} ; \mathrm{n}=5,3$ preparations) similar in amplitude and shape to that of a maximal dose of $\mathrm{CCh}$. Note, however, that the $\left[\mathrm{Ca}^{2+}\right]_{\mathrm{i}}$ does not fully return to baseline on switching perfusion to normal saline indicating ineffective washout of $\mathrm{CCK}$. A subsequent test with $\mathrm{CCh}$ resulted in no change in $\left[\mathrm{Ca}^{2+}\right]_{i}$ as would be expected for agonists operating to release $\mathrm{Ca}$ from a single intracellular pool that has previously been depleted by the CCK application. Similarly initial application of $\mathrm{CCh}$ followed, without an intervening interval in normal saline, with CCK resulted in no further change in $\left[\mathrm{Ca}^{2+}\right]_{i}$ (Fig. 4B). Insertion of an interval in normal saline subsequent to $\mathrm{CCh}$ application but prior to $\mathrm{CCK}$ stimulation resulted in an increase in $\left[\mathrm{Ca}^{2+}\right]_{i}$ by the second stimulus (Fig. $4 \mathrm{C}$ ). The resulting increase by $\mathrm{CCK}$ likely occurs from partial refilling of the agonist sensitive $\mathrm{Ca}$ pool prior to $\mathrm{CCK}$ 
stimulation. As shown in Fig. 4D exposure of acinar cells to $100 \mathrm{pM} \mathrm{CCK}$ resulted in a clear enhancement of oscillatory behavior of $\left[\mathrm{Ca}^{2+}\right]_{i}$ in these cells which was sustained throughout the $10 \mathrm{~min}$ period of agonist application. Similar enhanced oscillations were also seen in response to a submaximal concentration of $\mathrm{CCh}(1 \mu \mathrm{M})$.

\section{DISCUSSION}

The present study compares measurements using the Ca-sensitive fluorescent probe fura-2, of $\left[\mathrm{Ca}^{2+}\right]_{\mathrm{i}}$, in populations of cells and by microspectrofluorometry of single acinar cells. Differences in basal and CCh stimulated $\left[\mathrm{Ca}^{2+}\right]_{i}$ of acinar cells between the two approaches are not different from those of a number of previous reports on populations of acinar cells (3-8). Our results on single cells also substantiate the results of a number of others suggesting that $\mathrm{CCh}$ and $\mathrm{CCK}$ act to release $\mathrm{Ca}$ from the same intracellular agonist sensitive $\mathrm{Ca}$ pool as addition of a second agonist following a first elicits no additional rise in $\left[\mathrm{Ca}^{2+}\right]_{\mathrm{i}}$ (Fig. 4). These results, however, conclusively show for the first time that different agonists mobilize $\mathrm{Ca}^{2+}$ within the same cell.

There are also several differences between $\left[\mathrm{Ca}^{2+}\right]_{i}$ measurements obtained from single acinar cells and those obtained in prior studies from a fluorescence signal averaged over a large number of acini. One of these differences is the clear maintenance of an increased $\left[\mathrm{Ca}^{2+}\right]_{\mathrm{i}}$ above basal levels following the initial rapid rise in $\left[\mathrm{Ca}^{2+}\right]_{\mathrm{i}}$ induced by $\mathrm{CCh}$ or $\mathrm{CCK}$. Previous reports utilizing fura- 2 in stirred cells in a cuvette were interpreted as showing a return to basal $\left[\mathrm{Ca}^{2+}\right]_{\mathbf{i}}$ with sustained secretagogue application $(2,6,8,11)$. Utilizing the single cell approach we have observed a sustained increase above basal $\left[\mathrm{Ca}^{2+}\right]_{\mathrm{i}}$ in every cell in which agonist induced $\mathrm{Ca}$ mobilization was observed. The increase above basal is maintained for agonist applications up to $10 \mathrm{~min}$ (data not shown). The elucidation of these finer changes in $\left[\mathrm{Ca}^{2+}\right]_{i}$ near basal values was the result of a significantly higher signal to noise characteristic occurring as a result of reduced light scattering and autofluorescence in the superfused immobile acinar cells. A second difference we have observed relates to reloading of the agonist sensitive Ca pool. The lack of a significant difference between second responses to $\mathrm{CCh}$, either with $\mathrm{Ca}$ present only during the initial $\mathrm{CCh}$ challange, or absent throughout, suggests that reloading of the agonist sensitive Ca pool occurs only following removal of the agonist. This result is in contrast to that of Muallem et al. (11) who have reported that partial reloading of the agonist sensitive pool occurs during $\mathrm{CCh}$ application if extracellular $\mathrm{Ca}$ is present during agonist application. [ This conclusion, however, was based on application of ionomycin, the effects of which are not clearly understood in pancreatic acinar cells.] A third unique finding is that of oscillations in $\left[\mathrm{Ca}^{2+}\right]_{i}$ in response to agonist application. Clearly such oscillatory behavior is largely masked in populational studies as a result of the asynchrony of oscillations over the large number of cells which the fluorescent signal is measured. Oscillatory changes in $\left[\mathrm{Ca}^{2+}\right]_{\mathrm{i}}$ have recently been observed in single cell recording of 
several cell types (12-15). We have further observed that this oscillatory behavior becomes more prominent at lower doses of Ca mobilizing agonists as shown by Jacob et al. (16) for endothelial cells.

ACKNOWLEDGMENTS: Supported by NIH grants DK-32994 (JAW) and fellowship DK-07692 (ELS).

\section{REFERENCES}

1. Williams, J. A. and Hootman, S. R. (1986) In Exocrine Pancreas: Biology, Pathobiology and Diseases (V. L. W. Go, J. D. Gardner, F. P. Brooks, E. Lebenthal, E. P. DiMagno and G. A. Scheele Eds.), pp. 123-139. Raven Press, New York.

2. Pandol, S. J., Schoeffield, M. S., Fimmel, C. J. and Muallem, S. (1987). J. Biol. Chem. 262, 16963-16968.

3 Ochs, D. L., Korenbrot, J. I. and Williams, J. A. (1983). Biochem. Biophys. Res. Commun. 117, 122-128.

4. Pandol, S. J., Schoeffield, M. S., Sachs, G. and Muallem, S. (1985). J. Biol. Chem. 260, 10081-10086.

5. Ochs, D. L., Korenbrot, J. I. and Williams, J. A. (1985). Am. J. Physiol. 249, G389G398.

6. Bruzzone, R., Pozzan, T. and Wollheim, C. (1986). Biochem. J. 235, 139-143.

7. Merritt, J. E. and Rubin, R. P. (1985). Biochem. J. 230, 151-159.

8. Muallem, S., Schoeffield, M. S., Fimmel, C. J. and Pandol, S. J. (1988). Am. J. Physiol. 255, G221-G228.

9. Williams, J. A., Korc, M. and Dormer, R. L. (1978). Am. J. Physiol. 235, E517-E524.

10. Grynkiewicz, G., Poenie, M. and Tsien, R. Y. (1985). J. Biol. Chem. 260, 3440-3450.

11. Muallem, S., Schoeffield, M. S., Fimmel, C. J. and Pandol, S. J. (1988). Am. J. Physiol. 255, G229-235.

12. Roy Cuthbertson, K. S. and Cobbold, P. H. (1985). Nature 316, 541-542.

13. Woods, N. M., Roy Cuthbertson, K. S. and Cobbold, P. H. (1987). Cell Calcium 8, 79-100.

14. Kruskal, B. A. and Maxfield, F. r. (1987). J. Cell Biol. 105, 2685-2693.

15. Millard, P. J., Gross, D. Webb, W. W. and Fewtrell, C. (1980). Proc. Natl. Acad. Sci. USA 85, 1854-1858.

16. Jacob, R., Merritt, J. E., Hallam, T. J. and Rink, T. J. (1988). Nature 335, 40-45. 